DOI: $\underline{10.17805 / g g z .2020 .4 .6}$

\title{
Восприятие деревянных сельских церквей в постсоветской России (на примере Архангельской области)
}

А. С. Плужникова

\section{Московский гуманитарный университет}

В статье рассматривается проблема сохранения историко-архитектурного наследия Архангельской области. С 1918 г. по разным причинам продолжается интенсивное разрушение деревянных иерквей русского Севера периода Российской империи. Обычно сохраняются лишь фрагменты прежних ансамблей. Автор отмечает, что они важны для русской культурной идентичности. Требует решения вопрос о сохранении природного окружения иерквей.

В условиях недостаточного государственного финансирования основную роль в реставрации церквей с 2006 г. играют группь волонтеров. Делается вывод о том, что сокращение сельского населения делает перспективы сохранения большинства памятников архитектуры весьма мрачными.

Ключевые слова: культурное наследие; сельские деревянные иеркви; Русский Север; Архангельская область; волонтерское движение; фрагменты архитектурных комплексов

\section{Perception of the Wooden Rural Churches in the Post-Soviet Russia (The Case of Arkhangelsk Region)}

A. S. Pluzhnikova

Moscow University for the Humanities

The article considers the issue of the preservation of the historical and architectural heritage of Arkhangelsk region. Since 1918, an intensive destruction of wooden churches of the Russian North that were built in the times of the Russian empire has continued for various reasons. Usually, only fragments of previous ensembles are saved. The author notes that they are important for Russian cultural identity. The issue of preserving the natural environment of churches is to be solved.

Because of insufficient state funding volunteers has been playing the main role in the restoration of churches since 2006. It is concluded that the decrease of the rural population makes the prospects for preserving most of architectural monuments very bleak. 
Keywords: cultural heritage; rural wooden churches; Russian North; Arkhangelsk region; volunteer movement; fragments of architectural complexes

\section{ВВЕДЕНИЕ}

Деревянные церкви и часовни Русского Севера стали понемногу восприниматься как важная часть отечественного наследия еще с конца XIX в. Уж тогда вполне осознавалась и его уязвимость. Так, в 1889 г. В. В. Суслов писал: «Эти памятники, хранящие в себе непосредственное выражение народного гения... с каждым годом разрушаются и тем навсегда уносят следы нашей старой национальной жизни» (цит. по: Бокарев, 2018: Электронный ресурс). Еще в начале XX в. принимались первые меры для их защиты и сохранения.

Но лишь в начале 1960-х гг., во времена фундаментального оформления системы охраны памятников истории и культуры многие деревянные церкви были признаны «памятниками архитектуры, подлежащими охране как памятники государственного значения» (там же). В одной только Архангельской области на учет и охрану были поставлены десятки деревянных церквей и часовен. Увы, и позже даже официальная охрана зачастую не спасала эти здания от гибели в огне. Причин пожаров было много: неосторожное обращение местных жителей с огнем, пьяное хулиганство, удары молний...

\section{«УХОДЯЩИЕ» ДЕРЕВЯННЫЕ ЦЕРКВИ РУССКОГО СЕВЕРА}

В начале 1930-х гг. антицерковная политика Советского государства привела к тому, что почти все церковные здания были изъяты из ведения общин верующих. Закрытые церкви использовались на износ как склады, а то и просто разбирались. Еще одна беда постигла их по мере катастрофического запустения местных сел: они стояли без использования, ухода и элементарного ремонта.

Историческая территория Русского Севера в наши дни поделена между пятью субъектами Российской Федерации - Архангельской, Вологодской, Мурманской областями, республиками Карелия и Коми. В начале XIX в. на этой территории находилось около 1300 деревянных церквей. Из них древних храмов XVII-XVIII вв. перед революцией насчитывалось около 500. В течение XX в. были безвозвратно утрачены примерно две трети этого наследия. Сейчас на той же территории сохранились около 410 деревянных церквей, из которых 130 построены до XIX в. (там же).

После установления Советской власти разрушение деревянных церквей стало массовым. От рук «воинствующих безбожников» погибло большинство таких построек. Типична картина для приходов бывшего Кеврольского уезда: к началу XX в. здесь было 50 церквей, часовен и колоколен, а к началу XXI в. 
их осталось единицы. Такая же удручающая картина всеобщего разорения сельских и городских приходов наблюдалась и в других районах Архангельской области (Мильчик, Попова, 2002: 114).

Даже в областном центре - Архангельске — исчезли Свято-Троицкий кафедральный собор, Михайло-Архангельский монастырский собор, многие церкви (Рождественская, Архангельская городская, Воскресенская, Благовещенская, Рождественская, Успенская на Бору и др.); в Соломбале - Преображенский морской собор, церкви Преображения и Иоанна Рыльского.

Та же судьба постигла и Успенскую Боровскую церковь в Архангельске, известную тем, что ее колокольня из-за провала грунта стала напоминать знаменитую Пизанскую башню. В 1912 г. академик П. П. Покрышкин возглавил восстановительные работы, колокольню удалось спасти от обрушения. Однако в 1930-х гг. храм и колокольня были уничтожены (Ясински, Овсянников, 1998: 270-279; см. также: Овсянников, 1971).

К счастью, отдельные попытки реставрации деревянных культовых построек в регионе были предприняты еще в конце 1940-х гг. под руководством А. В. Ополовникова: они касались знаменитых храмов в Кижах, Кондопоге и Кеми. Увы, некоторые результаты современной реставрации вызывают недоумение и в какой-то мере отражают отношение местных светских и церковных властей и деятелей культуры к наиболее старым постройкам. Характерный пример: попытка реставрации Рождественской церкви 1678 г. в Бережной Дуброве. Этот многоглавый храм долгие годы пребывал на грани разрушения. Но реставрационные работы 2015-2016 гг. историческую часть здания почему-то не затронули. Была полностью разобрана до основания трапезная конца XIX столетия, а взамен в том же размере построена новая, стилизованная под постройки XVIII в. (Бокарев, 2018: Электронный ресурс).

Строительство деревянных храмов Русского Севера указывало на соответствие архитектурного облика традициям, старым образцам церквей. Как фиксируют порядные документы, христианские постройки строились «по подобию», при этом каждая из них, разумеется, была уникальна. Она строилась, видимо, еще по языческой традиции, в точке, идеально красивой с соседних деревень и перекрестков дорог (Ушаков, 1982: 158). А такая сложившаяся система имитации старых форм тоже берет свое зарождение в глубокой древности и имеет определенный магический смысл: ведь подражание было одним из основных видов магических действий. Языческая культура была скорее преобразована христианством, чем уничтожена, наполнив ее более возвышенным новым содержанием. Народу были даны новые образцы, а их копирование осуществлялось, главным образом, для создания подобия священного оригинала (Пермиловская, 2018: 340). Характерно, что и первым каменным храмом на территории области стал Архангело-Михайловский со- 
бор бывшего Михайло-Архангельского монастыря в Нячерах (1685-1699 гг.). Важными вкладчиками на его строительство были соправители Петр I и Иван V (Бондаренко, 2017: 190-191).

Русская северная архитектура была, в основном, представлена деревянными церквями и часовнями нескольких типов: клетские, шатровые, кубоватые, ярусные, многоглавые (за исключением часовен). Среди сохранившихся самые древние - это клетские, в основании которых лежит четырехстенная клеть, которая перекрыта двускатной кровлей. В качестве примера можно привести церковь Воскрешения Лазаря Муромского на острове Кижи (XIV в.), церковь Ризоположения из села Бородава (1485 г.; Вологодская область), Георгиевская церковь в селе Юксовичи (1493 г.; Ленинградская область).

В качестве примеров более поздних (со второй половины XVI в.) шатровых храмов можно назвать следующие: Никольская церковь в селе Лявля (1581; Приморский район), Георгиевская церковь в селе Вершина (1672; Архангельская область), церковь Димитрия Солунского в селе Верхняя Уфтюга (1784; Красноборский район). Бассейн реки Онеги, на побережьях Белого моря Карелии и Поморского районов сохранил достаточное количество пятиглавых храмов с кубоватым покрытием, среди них: Троицкая церковь в селе Подпорожье (между 1725 и 1727; Онежский район), Преображенская церковь в деревне Турчасово (1786; Онежский район). Как мы видим, каждой территориальной единице Русского Севера были свойственны особенные виды архитектурных композиций (Мильчик, Ушаков, 1981: 121-122).

Со времен появления в XV-XVI вв. на малолюдном и суровом Севере скитов и монастырей в русской культуре Русский Север воспринимается как символ веры во что-то «светлое», святое и одновременно - в каком-то смысле первозданное (ср., например: Шмелев, 2014). Именно Север стал обителью «глубокого» русского монашества, в частности это Северная Фиваида, названная А. Н. Муравьевым «Русской Фиваидой». Во главе монастырского «освоения» северных земель стояли сподвижники и ученики Кирилла Белозерского и Сергия Радонежского: «Преподобный Сергий стоит во главе всех, на южном краю сей чудной области и посылает внутрь ее своих учеников и собеседников, а преподобный Кирилл, на другом ее краю, приемлет новых пришельцев и расселяет обители окрест себя, закидывая свои пустынные мрежи даже до Белого моря и на острова Соловецкие» (Муравьев, 1855: 41; см.: Пермиловская, 2015). Со времен перестройки это видение вновь стало распространенным. 


\section{РЕШЕНИЕ ПРОБЛЕМЫ СОХРАНЕНИЯ ПАМЯТНИКОВ ДЕРЕВЯННОГО ЗОДЧЕСТВО}

В деле сохранения наследия принимают участие местные жители и группы энтузиастов из крупных городов. Их финансовые возможности, разумеется, существенно уступают возможностям государства (последнее субсидировало реставрацию некоторых объектов в рамках программы «Культура Русского Севера» с 2005 г.). Однако ответственный подход к делу и горячее желание сохранить памятники позволяют небольшим добровольным объединениям добиваться значимых результатов и при скромном бюджете. Среди общественных движений по широте охвата памятников особенно выделяется проект «Общее дело» (https://obsheedelo.ru/), который стихийно возник в 2006 г. благодаря 75-летнему А. П. Слепнину из села Ворзогоры. В его рамках активисты организуют несколько десятков волонтерских экспедиций в самые разные местности Русского Севера. Помимо «Общего дела», отметим благотворительный фонд «Вереница», выросший в 2014 г. из движения добровольных помощников реставраторов (http://verenitsa.ru/). Их основные объекты расположены в бассейне реки Ваги. Некоторые церкви восстанавливаются независимыми инициативными группами, в основном организованными местными жителями.

За последнее десятилетие волонтерами были проведены консервационные работы более чем на сотне церквей и часовен. В их числе такие значимые, как Владимирская церковь (1757) в Подпорожье и Преображенская церковь (1786) в Турчасово, Сретено-Михайловская церковь (1665) в Красной Ляге и церковь Рождества Христова (1745) в Большой Шалге, Никольская церковь (1790) в Гридинской, Владимирская церковь (1759) в Меландове, Ильинская церковь (1798) в Сельце. Срочные работы, предотвратившие окончательное разрушение руинированных памятников, касались Ильинской церкви (1622) в Задней Дуброве и Никольской церкви (1670) в Волосово. Срочные работы, предотвратившие окончательное разрушение руинированных памятников, касались Ильинской церкви (1622) в Задней Дуброве и Никольской церкви (1670) в Волосово (Бокарев, 2018: Электронный ресурс). К ним стоит добавить серию церквей XIX в. в Архангельской и Вологодской областях, многие часовни XVIII-XIX вв. Важной стороной многих таких работ являются попытки сохранить природное окружение восстанавливаемых зданий.

Сейчас делается упор на сохранении аутентичности и воссоздании первоначального вида народной архитектуры, что позволяет выявить более глубокие смыслы местных и общерусских традиций. В сохранении и популяризации культурной идентичности Русского Севера (во многом - благодаря изучению народной архитектуры) явственна народная метафора, берущая 
свое начало в строительных терминах древнерусского деревянного зодчества: «Как мера и красота скажут» (Пермиловская, 2013: 153).

\section{ЗАКЛЮЧЕНИЕ}

В православии высшим проявлением народного зодчества всегда было храмостроительство, деревянные образцы которой превратили Русский Север в уникальный заповедник древнерусской церковной архитектуры. Это местное ответвление традиций, впитавших в себя этническое христианское мировоззрение (Пермиловская, 2018: 341).

Отметим, что из 130 построек XV-XVIII вв. статус объектов культурного наследия федерального значения имеет чуть более половины. Остальные 60 храмов XVI-XVIII столетий и около 280 деревянных церквей, построенных до революции и еще сохраняющихся на территории Русского Севера, в лучшем случае имеют статус памятников регионального значения. Понятно, что государственного финансирования со стороны регионов эти постройки не дождутся. Часть из них помогает сохранить волонтерское движение. Среди прочего, большинство некогда прекрасных ансамблей из нескольких зданий сохранилось лишь в небольших фрагментах. Многие здания будут утрачены в ближайшие десятилетия: ведь без возрождения сельской жизни в недавно заброшенных местностях шансов на спасение у них практически нет. Проблема сохранения культурного наследия в обезлюдивших краях, вдали от городов, стоит очень остро.

\section{СПИСОК ЛИТЕРАТУРЫ}

Бокарев, А. (2018) Деревянные храмы Русского Севера в начале XXI века [Электронный ресурс] // Хранители наследия. 12 октября. URL: https://hraniteli-nasledia.com/articles/nasledie-rossii/derevyannye-khramy-russkog o-severa-v-nachale-xxi-veka/ [архивировано в WaybackMachine] (дата обращения: 21.06.2020).

Бондаренко, И. А. (2017) Теория в истории архитектуры и градостроительства: публикации разных лет. СПб. : Коло. 832 с.

Мильчик, М. И., Попова, Л. Д. (2002) Первые ворота Российского государства: очерки градостроительной и архитектурной истории Архангельска и Холмогор. СПб. : Лики России. 224 с.

Мильчик, М. И., Ушаков, Ю. С. (1981) Деревянная архитектура Русского Севера: страницы истории. Л. : Стройиздат. 128 с.

Муравьев, А. Н. (1855) Русская Фиваида на Севере. СПб. : Типогр. III Отд. Собственной Е. И. В. канцелярии. [8], 507 с.

Овсянников, О. В. (1971) Люди и города Средневекового Севера. Архангельск : Северо-Западное книжное издательство. $81 \mathrm{c.}$ 
Пермиловская, А. Б. (2013) Культурные смыслы народной архитектуры Русского Севера. Екатеринбург : УрО РАН ; Архангельск : ОАО «ИПП “Правда Севера"»; Ярославль : ЯГПУ имени К. Д. Ушинского. 608 с.

Пермиловская, А. Б. (2015) Деревянный храм в контексте изучения русской традиционной культуры в динамике ее становления и трансформации // В мире научных открытий. № 5-7 (65). С. 2341-2360. DOI: $\underline{10.12731 / \text { wsd-2015-5.7-2 }}$

Пермиловская, А. Б. (2018) Культовая народная архитектура как явление русской национальной культуры (по материалам Русского Севера и Арктики) // Ярославский педагогический вестник. № 5. С. 336-344. DOI: 10.24411/1813-145X-2018-10182

Ушаков, Ю. С. (1982) Ансамбль в народном зодчестве русского Севера (пространственная организация, композиционные приемы, восприятие). Л. : Стройиздат. $168 \mathrm{c.}$

Шмелев, И. С. (2014) Старый Валаам : очерк . М. : Сибирская Благозвонница. 187, [1] с.

Ясински, М. Э., Овсянников, О. В. (1998) Взгляд на Европейскую Арктику: Архангельский Север: проблемы и источники : в 2 т. СПб. : Петербургское востоковедение. Т. 1.464 с.

Дата поступления: 14.07.2020 г.

\section{REFERENCES}

Bokarev, A. (2018) Dereviannye khramy Russkogo Severa v nachale XXI veka [Wooden temples of the Russian North in the early 21st century]. Khraniteli naslediia, October 12. [online] Available at: https://hraniteli-nasledia.com/articles/ nasledie-rossii/derevyannye-khramy-russkogo-severa-v-nachale-xxi-veka/ [archived in WaybackMachine] (accessed 21.06.2020). (In Russ).

Bondarenko, I. A. (2017) Teoriia $v$ istorii arkhitektury $i$ gradostroitel'stva: Publikatsii raznykh let [Theory in the history of architecture and urban development: Publications of different years]. St. Petersburg : Kolo Publ. 832 p. (In Russ.).

Milchik, M. I. and Popova, L. D. (2002) Pervye vorota Rossiiskogo gosudarstva: Ocherki gradostroitelnoi $i$ arkhitekturnoi Arkhangelska $i$ Kholmogor [First gateway of the Russian state: Sketches of town-planning history of Arkhangelsk and Kholmogory]. St. Petersburg : Liki Rossii Publ. 224 p. (In Russ.).

Milchik, M. I. and Ushakov, Yu. S. (1981) Dereviannaia arkhitektura Russkogo Severa: stranitsy istorii [Wooden architecture of the Russian North: The pages of history]. Leningrad : Stroiizdat Publ. 128 p. (In Russ.). 
Muravyov, A. N. (1855) Russkaia Fivaida na Severe [Russian Thebais in the North]. St. Petersburg : Printing Office of the Third Section of His Imperial Majesty's Own Chancellery. [8], 507 p. (In Russ.).

Ovsiannikov, O. V. (1971) Liudi i goroda srednevekovogo Severa [Peoples and cities of the medieval North]. Arkhangelsk : Northwestern Publ. House. 81 p. (In Russ.).

Permilovskaya, A. B. (2013) Kulturnye smysly narodnoi arkhitektury russkogo Severa [Cultural meanings of folk architecture of the Russian North]. Ekaterinburg : Ural Branch of the Russian Academy of Sciences ; Arkhangelsk : Pravda Severa Publ. ; Yaroslavl : Yaroslavl State Pedagogical University named after K. D. Ushinsky. 608 p. (In Russ.).

Permilovskaya, A. B. (2015) Dereviannyi khram v kontekste izucheniia russkoi traditsionnoi kul'tury $\mathrm{v}$ dinamike ee stanovleniia i transformatsii [Wooden temple in the context of the Russian traditional culture studying in the dynamics of its becoming and transformation]. $V$ mire nauchnykh otkrytii, no. 5-7 (65), pp. 2341-2360. (In Russ.). DOI: 10.12731/wsd-2015-5.7-2

Permilovskaya, A. B. (2018) Kul'tovaia narodnaia arkhitektura kak iavlenie russkoi natsional'noi kul'tury (po materialam Russkogo Severa i Arktiki) [Temple national architecture as a Russian traditional culture phenomenon (On the Russian North and Arctic materials)]. Iaroslavskii pedagogicheskii vestnik, no. 5, pp. 336344. (In Russ.). DOI: 10.24411/1813-145X-2018-10182

Ushakov, Yu. S. (1982) Ansambl'v narodnom zodchestve russkogo Severa (prostranstvennaia organizatsiia, kompozitsionnye priemy, vospriiatie) [Ensemble in the folk architecture of the Russian North (Spatial organization, compositional techniques, perception)]. Leningrad : Stroiizdat Publ. 168 p. (In Russ.).

Shmelev, I. S. (2014) Staryi Valaam [The old Valaam] : An essay. Moscow : Sibirskaia Blagozvonnitsa Publ. 187, [1] p. (In Russ.).

Jasinski, M. E. and Ovsiannikov, O. V. (1998) Vzgliad na Evropeiskuiu Arktiku: Arkhangel'skii Sever: problemy i istochniki [European Arctic. Archangel region: research problems and sources] : in 2 vols. St. Petersburg : Peterburgskoe vostokovedenie Publ. Vol. 1. 464 p. (In Russ.).

Submission date: 14.07.2020.

Плужникова Анастасия Сергеевна - магистрант кафедры философии, социологии и культурологии Московского гуманитарного университета. Адpec: 111395, Россия, г. Москва, ул. Юности, 5. Тел.:+7 (499) 374-60-21. Эл. адрес: philosophy@mosgu.ru. Научный руководитель — д-р ист. н., проф. С. А. Яценко. 
Pluzhnikova Anastasiia Sergeevna, Master's Degree Student, Department of Philosophy, Sociology and Culturology, Moscow University for the Humanities. Postal address: 5 Yunosti St., 111395 Moscow, Russian Federation. Tel.:+7 (499) 374-60-21. E-mail: philosophy@mosgu.ru. Research adviser: S. A. Yatsenko, Doctor of History, Professor.

Для цитирования:

Плужникова А. С. Восприятие деревянных сельских церквей в постсоветской России (на примере Архангельской области) [Электронный ресурс] // Горизонты гуманитарного знания. 2020. № 4. C. 98-106. URL: https://journals. mosgu.ru/ggz/article/view/1309 (дата обращения: дд.мм.гггг). DOI: 10.17805/ ggz.2020.4.6 